\title{
Severe Acute Respiratory Syndrome Coronavirus 3a Protein Is a Viral Structural Protein
}

\author{
Naoto Ito, ${ }^{1,2}+$ Eric C. Mossel,,${ }^{1} \dagger$ Krishna Narayanan, ${ }^{1}$ Vsevolod L. Popov, ${ }^{3}$ Cheng Huang, ${ }^{1}$ \\ Taisuke Inoue, ${ }^{1}$ Clarence J. Peters, ${ }^{1,3}$ and Shinji Makino ${ }^{1 *}$ \\ Departments of Microbiology and Immunology ${ }^{1}$ and Pathology, ${ }^{3}$ The University of Texas Medical Branch at Galveston, \\ Galveston, Texas, and Laboratory of Zoonotic Diseases, Division of Veterinary Medicine, Faculty of Applied \\ Biological Science, Gifu University, Gifu, Japan ${ }^{2}$
}

Received 4 August 2004/Accepted 20 October 2004

\begin{abstract}
The present study showed the association of a severe acute respiratory syndrome coronavirus (SCoV) accessory protein, 3a, with plasma membrane and intracellular SCoV particles in infected cells. 3a protein appeared to undergo posttranslational modifications in infected cells and was incorporated into SCoV particles, establishing that 3a protein was a $\mathrm{SCoV}$ structural protein.
\end{abstract}

Severe acute respiratory syndrome (SARS) coronavirus $(\mathrm{SCoV})$ is the etiological agent of a new emerging infectious disease, SARS, which originated in southern China in 2002 and spread to various areas of the world in the 2003 epidemic (5, $11,12,23,29)$. Like all coronaviruses, the SCoV genome carries the most $5^{\prime}$-end gene 1 , which encodes proteins for viral RNA synthesis; four viral structural protein genes, S, M, E, and $\mathrm{N}$; and several (about eight) putative accessory genes $(16,25$, 28). The biological functions of coronavirus accessory proteins are poorly characterized. In most cases, they are dispensable for virus replication in cell culture while some appear to contribute to viral pathogenesis $(1-3,21,22,30,31)$. In mouse hepatitis virus, the accessory protein, I protein, is a viral structural protein (9). Among the putative SCoV accessory genes, the $3 \mathrm{a}$ gene product, $3 \mathrm{a}$ protein, was detected in SCoV-infected cells and in the lungs of SARS patients (32); the 3a gene is also called X1 (25) and U274 (27). Topology prediction of 3a protein based on the amino acid sequence suggests that $3 \mathrm{a}$ is a type III transmembrane protein with three transmembrane domains.

To examine 3a protein synthesis in SCoV-infected cells, accumulation of $3 \mathrm{a}$ protein in $\mathrm{Caco} 2$ cells that were infected with the Urbani strain of SCoV was examined by Western blot analysis with anti-3a antibody. Anti-3a antibody was prepared by injection of a purified glutathione $S$-transferase (GST)-3a fusion protein (amino acids 127 to 274 of 3 a protein were fused with the C terminus of GST protein), expressed in Escherichia coli, into a rabbit and subsequent affinity purification of the serum by the GST-3a fusion protein. Several 3a-related signals were detected in SCoV-infected cells and not in mock-infected cells (Fig. 1). Among them, a 31-kDa protein, which corresponded to the predicted size $(30.9 \mathrm{kDa})$ of $3 \mathrm{a}$ protein, was most abundant (Fig. 1, arrow). Translation of in vitro-synthesized, capped RNA transcripts carrying the 3a gene in rabbit reticulocyte lysate also resulted in the production of $31-\mathrm{kDa}$

\footnotetext{
* Corresponding author. Mailing address: Department of Microbiology and Immunology, The University of Texas Medical Branch at Galveston, Galveston, TX 77555-1019. Phone: (409) 772-2323. Fax: (409) 772-5065. E-mail: shmakino@utmb.edu.

$\dagger$ N.I. and E.C.M. contributed equally to this study.
}

protein (data not shown), suggesting that the major 31-kDa protein represented an unmodified 3a protein in infected cells. Besides the 31-kDa major band, several larger, faint bands ranging from 34 to $41.5 \mathrm{kDa}$ were detected, suggesting posttranslational modification of the protein. The nature of $3 \mathrm{a}$ protein modification requires further studies. The presence of two smaller bands of approximately 25.5 and $26.5 \mathrm{kDa}$ in infected cells suggested that some 3 a protein molecules underwent specific proteolytic processing and/or that these two signals represented quasistable degradation products.

Analysis of the subcellular distribution of 3 a protein by confocal microscopy with anti-3a antibody demonstrated the cytoplasmic localization of $3 \mathrm{a}$ protein in SCoV-infected cells (Fig. 2A). Strong signals were also detected at peripheral regions of the infected cells. No signal was detected in mock-infected cells (Fig. 2B).

Analysis of the subcellular localization of $3 a$ protein in $\mathrm{SCoV}$-infected $\mathrm{Caco} 2$ cells by immunoelectron microscopy with anti-3a antibody showed that 3a protein was localized in the cytoplasm as well as at the plasma membrane (Fig. 3A and B), whereas the nucleus of the infected cells (Fig. 3A) and uninfected cells (one cell at the upper left corner in Fig. 3A; also Fig. 3D) showed only background signals. More importantly, 3a protein was distributed in cytoplasmic (Fig. 3A and C) and plasma membrane (Fig. 3B, "V") regions in which many virus particles had accumulated. Essentially the same subcellular localization of 3 a protein was detected in infected Vero E6 cells (data not shown). To eliminate the possibility of nonspecific binding of anti-3a antibody to $\mathrm{SCoV}$, we counted the number of intracellular virus particles labeled with 3aspecific immunogold signals in immunoelectron micrographs of SCoV-infected $\mathrm{Caco} 2$ cells stained with anti-3a antibody or the preimmune serum. Out of 200 virus particles counted randomly, 75 particles $(37.5 \%)$ had the immunogold label in the cells stained with anti-3a antibody, while only 7 (3.5\%) had signals in the cells stained with preimmune serum. The difference was statistically significant, as determined by the chisquare test $(P<0.001)$, establishing the association of $3 \mathrm{a}$ protein with $\mathrm{SCoV}$. These data suggested that 3 a protein could be incorporated into SCoV particles. The data obtained from 


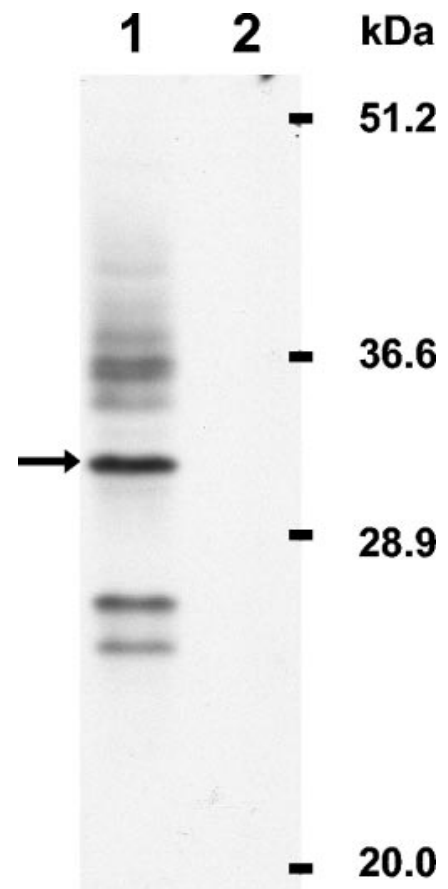

FIG. 1. Western blot analysis of 3 a protein. Human colonic adenocarcinoma Caco2 cells were infected with $\mathrm{SCoV}$ at a multiplicity of infection of 0.01 , and cells were solubilized with sodium dodecyl sulfate-polyacrylamide gel electrophoresis sample buffer (100 mM Tris$\mathrm{HCl}$ [pH 6.8], $4 \%$ sodium dodecyl sulfate, $0.2 \%$ bromophenol blue, $20 \%$ glycerol, and $200 \mathrm{mM}$ beta-mercaptoethanol) at 5 days p.i. Cell extracts were applied to a sodium dodecyl sulfate-15\% polyacrylamide gel, and Western blot analysis was performed using anti-3a antibody. Lane 1, SCoV-infected Caco2 cells; lane 2, mock-infected Caco2 cells. Arrow; major 31-kDa 3a protein.

these microscopic analyses were consistent with the report of 3 a protein association with cytoplasmic membrane in 3a protein-expressing cells (27) and a confocal microscopic study demonstrating that 3 a protein was distributed over the cyto-
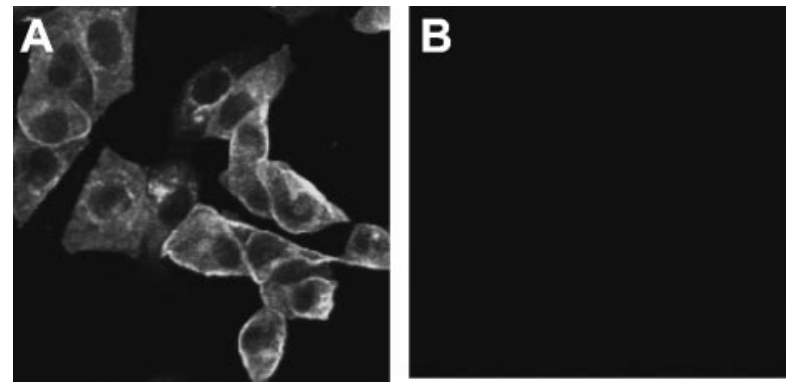

FIG. 2. Confocal microscopic analysis of 3a protein in SCoV-infected cells. Vero E6 cells growing in eight-well chamber slides (LabTek, Naperville, Ill.) were infected with $\mathrm{SCoV}$ at a multiplicity of infection of 1 (A) or mock infected (B). At 24 h p.i., cultures were incubated overnight with $4 \%$ paraformaldehyde and then treated with $0.25 \%$ Triton X-100 for 15 min. Subsequently, cells were incubated with anti-3a antibody and goat anti-rabbit secondary antibody conjugated with Alexa Fluor 488 dye (Molecular Probes, Eugene, Oreg.). Cells were observed under the Zeiss LSM 510 UV META laser scanning confocal microscope in the University of Texas Medical Branch Infectious Disease and Toxicology Optical Imaging Core. plasm and was partly concentrated in the Golgi apparatus of infected cells (32).

To test the possibility that 3 a protein is a viral structural protein, the presence of $3 \mathrm{a}$ protein in the purified SCoV was examined. To minimize the possible copurification of intracellular proteins with the purified SCoV, we propagated SCoV in Caco2 cells, which did not show any visible cytopathic effects during SCoV replication (17). Prior to SCoV purification, culture supernatants from $\mathrm{SCoV}$-infected $\mathrm{Caco} 2$ cells were irradiated frozen with $2 \times 10^{6}$ rads from a Gammacell ${ }^{60} \mathrm{Co}$ source (model 109A; JL Shepherd and Associates, San Fernando, Calif.). After confirmation of the complete inactivation of virus infectivity, the sample was clarified by centrifugation at $450 \times$ $g$ for $15 \mathrm{~min}$. SCoV particles were partially purified by two subsequent ultracentrifugations on a discontinuous sucrose gradient consisting of $60,50,30$, and $20 \%$ sucrose with the use of a Beckman SW28 rotor $(10,19)$; the sample was first centrifuged at 28,000 rpm for $3 \mathrm{~h}$, and the virus particles at the interface of 30 and $50 \%$ sucrose were further centrifuged at $28,000 \mathrm{rpm}$ for $18 \mathrm{~h}$. The virus particles at the interface of 30 and $50 \%$ sucrose were collected, diluted, and then further applied on a continuous sucrose gradient of 20 to $60 \%$ sucrose. The samples were centrifuged at 28,000 rpm for $18 \mathrm{~h}$. Subsequently, 10 fractions were collected, and sucrose density in each fraction was measured. $\mathrm{SCoV}$ in each fraction was pelleted through a $20 \%$ sucrose cushion at $38,000 \mathrm{rpm}$ for $2 \mathrm{~h}$ with a Beckman SW41 rotor. The pellet in each fraction was subjected to Western blot analysis with anti-N protein antibody (kindly provided by Xiao-Hua $\mathrm{Li}$ ), anti-M protein antibody (Abgent, San Diego, Calif.), and anti-3a antibody (Fig. 4A). Analysis of $\mathrm{N}$ protein and $\mathrm{M}$ protein demonstrated the distribution of the purified SCoV in the continuous sucrose gradient. The strongest signals of $\mathrm{N}$ and $\mathrm{M}$ proteins were detected in fractions 6 (sucrose density, $1.185 \mathrm{~g} / \mathrm{ml}$ ) and 7 (sucrose density, $1.160 \mathrm{~g} / \mathrm{ml}$ ), suggesting that the buoyant density of SCoV was similar to that of mouse hepatitis virus $(14,15)$. In addition to $\mathrm{N}$ protein of approximately $50 \mathrm{kDa}$, a signal of $\sim 40$ $\mathrm{kDa}$ was also detected in the purified SCoV. The $40-\mathrm{kDa}$ species of $\mathrm{N}$ protein, which was barely detected in infected cells, was probably produced from the $50-\mathrm{kDa} \mathrm{N}$ protein by proteolytic processing. $\mathrm{N}$ protein of transmissible gastroenteritis coronavirus is cleaved by activated caspases in infected cells (6), while the mechanism of proteolytic processing of SCoV N protein is unknown. Multiple $\mathrm{M}$ protein signals indicated the presence of various glycosylated forms of $\mathrm{M}$ protein in $\mathrm{SCoV}$ particles. Like $\mathrm{N}$ and $\mathrm{M}$ proteins, several 3a protein-related signals were detected in fractions from 5 to 8 , with the highest signal in fractions 6 and 7. Although most of the intracellular 3a-related signals were detected in purified SCoV, a $25.5-\mathrm{kDa}$ signal was not detected in the purified SCoV. Also two signals (asterisks), which were prominent in purified $\mathrm{SCoV}$, were not detected in infected cells. These data strongly suggested that 3 a protein was a viral structural protein.

To eliminate a possibility that the 3 a protein detected in purified SCoV represented a copurified intracellular 3a protein contaminant that was released into the culture fluids or that was associated with cell debris, Western blot analysis was performed to examine whether the intracellular host protein, actin, and the SCoV gene 1 protein, nsp1 (24), which is believed to be a nonstructural protein, were also found in the 


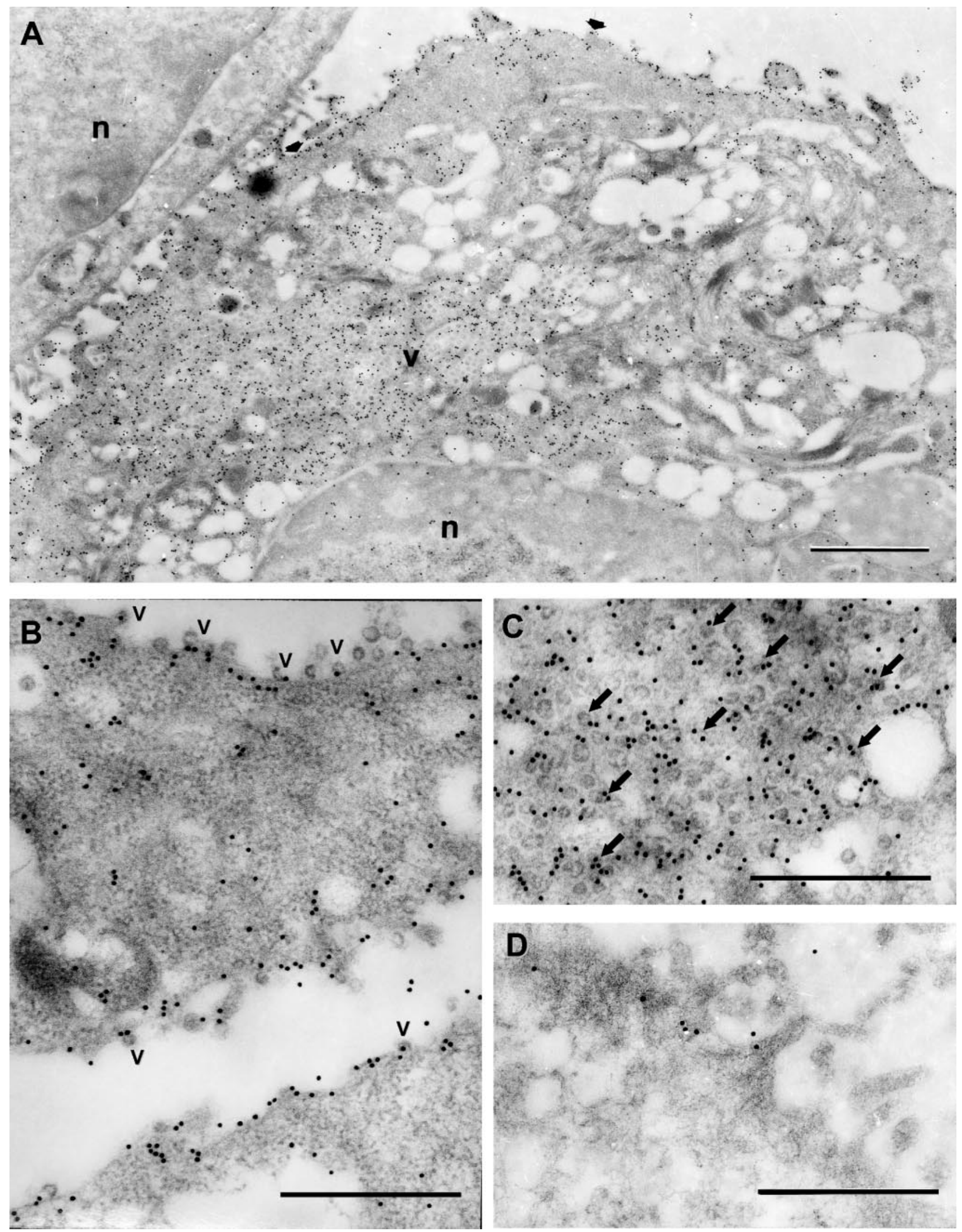


purified SCoV (Fig. 4B); detection of actin and nsp1 proteins in the purified $\mathrm{SCoV}$ sample would indicate that the virus purification procedure was not appropriate. Antiactin goat polyclonal immunoglobulin G (I-19; Santa Cruz Biotechnology, Santa Cruz, Calif.) was used to detect actin. Anti-nsp1 antibody was raised in rabbits by immunizing them with the synthetic peptide (N-RKNGNKGAGGHSYG-C). Analysis of intracellular proteins from uninfected $\mathrm{Caco} 2$ cells and infected Caco 2 cells at 5 days postinfection (p.i.) showed the presence of nsp1 only in infected cell extracts and actin in both cell extracts. Both actin and nsp1 proteins were not detected in the purified SCoV. Consistent with the data shown in Fig. 4A, N and $3 \mathrm{a}$ proteins were detected in purified $\mathrm{SCoV}$ and $\mathrm{SCoV}$ infected cells but not in uninfected cells. These data strongly indicated that $3 \mathrm{a}$ protein in the purified SCoV sample was not a copurified intracellular 3 a protein contaminant.

Our electron microscopic analysis convincingly showed the association of 3 a protein with intracellular SCoV, as well as SCoV particles at the plasma membrane (Fig. 3). Western blot analysis demonstrated the presence of 3 a protein in the purified SCoV (Fig. 4A). The species of 3a protein detected in the purified virion was not identical to that observed in the infected cells, indicating that 3 a protein found in the purified $\mathrm{SCoV}$ was not an intracellular 3 a protein contaminant (Fig. 4). The absence of actin and SCoV nsp1 proteins in the purified SCoV sample further confirmed that our virus purification method was appropriate (Fig. 4B). Based on these data we concluded that the 3 a protein was a viral structural protein. A recent study revealed that a highly purified transmissible gastroenteritis coronavirus preparation is possible by the use of an immunopurification method (7). However, we were unable to use this new method to purify SCoV due to the lack of an appropriate monoclonal antibody. Analysis of highly purified SCoV samples by the immunopurification method may be useful to study the stoichiometric amount of $3 \mathrm{a}$ protein in the purified SCoV relative to other structural proteins.

Assembly of coronavirus S protein, E protein, and nucleocapsid is mediated by binding of these molecules to $\mathrm{M}$ protein in infected cells $(4,8,10,13,18,20,26)$. Coimmunoprecipitation studies demonstrated that expressed 3 a protein interacts with coexpressed SCoV M, E, and S proteins (27). A recent study using a crude SCoV preparation indicated the presence of interaction between 3a protein and S protein (33). Although these interactions have not been experimentally demonstrated in infected cells, the presence of $3 \mathrm{a}$ protein in SCoV indicates that the incorporation of $3 \mathrm{a}$ protein into $\mathrm{SCoV}$ particles was mediated by the interaction with viral envelope proteins at the virus budding sites. Further studies are required to determine whether association of $3 \mathrm{a}$ protein with $\mathrm{SCoV}$ particles has some role in SCoV assembly.
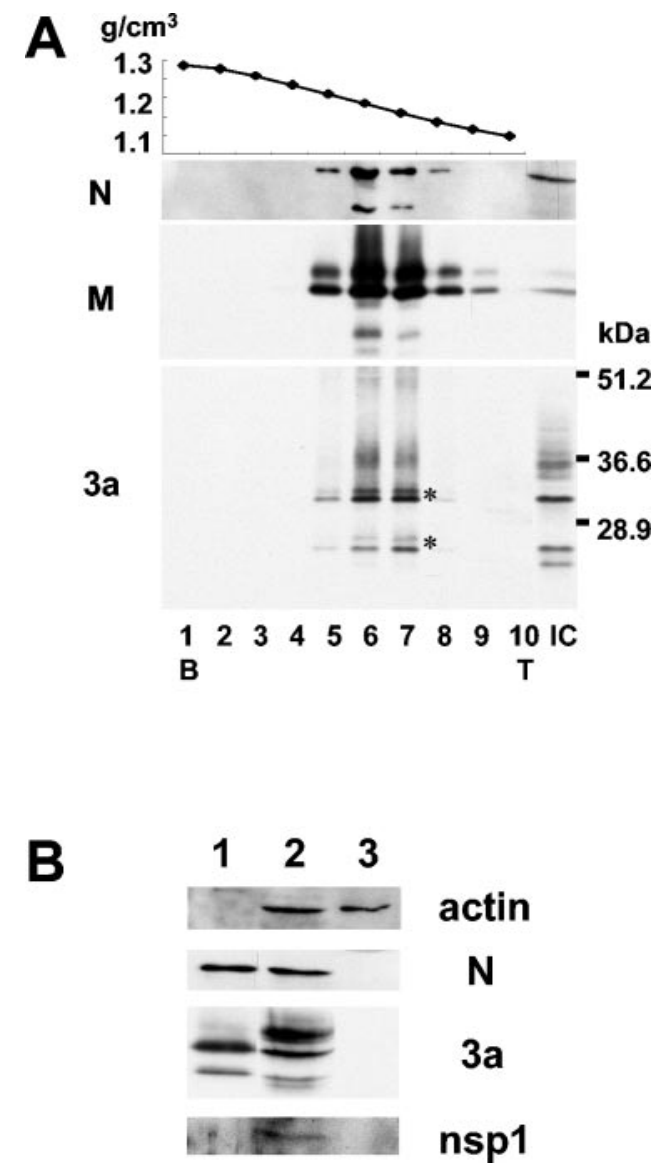

FIG. 4. Western blot analysis of N, M, and 3a proteins in purified $\mathrm{SCoV}$. Caco2 cells were infected with $\mathrm{SCoV}$ at a multiplicity of infection of 1 , and culture fluid was collected at 5 days p.i. Released SCoV was purified by sucrose gradient centrifugation as described in the text. (A) Ten fractions from a 20 to $60 \%$ sucrose gradient containing the virus particles were collected and numbered from bottom (B) to top (T) of the gradient. The top panel represents the density of each sucrose fraction. IC, intracellular proteins from $\mathrm{SCoV}$-infected $\mathrm{Caco} 2$ cells. (B) Purified SCoV (lane 1), cell extracts from SCoV-infected Caco 2 cells at 5 days p.i. (lane 2), and uninfected $\mathrm{Caco} 2$ cells at 5 days p.i. (lane 3 ) were analyzed for actin protein, $\mathrm{N}$ protein, 3 a protein, and SCoV nsp1 protein.

3a protein carries a signal that may be important for rapid internalization of the protein from the plasma membrane (27). If $3 \mathrm{a}$ protein interacts with a host protein(s) in the plasma membrane, then there is a possibility that the complex of this putative host protein and 3 a protein may be rapidly internalized. It will be interesting to test whether virion-associated $3 \mathrm{a}$ protein downregulates the expression of some of the mem-

FIG. 3. Immunogold labeling of 3a protein in SCoV-infected cells. Caco2 cells were infected with SCoV at a multiplicity of infection of 0.5 , fixed at $48 \mathrm{~h}$ p.i., and embedded in LR White resin. Ultrathin sections of the cells were incubated with anti-3a antibody and goat anti-rabbit immunoglobulin G (heavy plus light) conjugated to 15 - $\mathrm{mm}$ colloidal gold particles (Amersham Biosciences). (A) In a SCoV-infected cell the label is clearly associated with intracellular virus (v) and with the virions at the cell surface (arrows). An uninfected cell in the upper left corner is devoid of label. $\mathrm{n}$, nucleus. Bar $=1 \mu \mathrm{m}$. (B) 3a protein is associated with plasma membranes. V, SCoV particles associated with 3a protein. (C) Association of 3a protein with intracellular virus particles (arrows). (D) Portion of cytoplasm of a mock-infected Caco2 cell showing occasional staining of a few gold particles near the plasma membrane. Bars (B to D) $=0.5 \mu \mathrm{m}$. 
brane-associated host proteins to evade host immune responses and/or alter the cellular environment to one that is suitable for virus replication.

We thank Bo Xu at the Biomolecular Resource Facility, University of Texas Medical Branch, for valuable support for preparation of anti-3a antibody and Xiao-Hua $\mathrm{Li}$ at The Center for Biomedical Inventions, University of Texas Southwestern at Dallas, for anti-N antibody. We are also grateful to Eugene P. Knutson at the Infectious Disease and Toxicology Optical Imaging Core, University of Texas Medical Branch, for confocal microscopic analysis and Violet C. Han at the Electron Microscopy Laboratory at University of Texas Medical Branch Department of Pathology for expert assistance in electron microscopy.

This work was supported by Public Health Service grant AI29984 to S.M. and contract AI25489 to C.J.P. from the National Institutes of Health. N.I. was supported by a fellowship for long-term overseas research for young investigators sponsored by the Ministry of Education, Culture, Sports, Science and Technology, Japan. E.C.M. and C.H. were supported by NIH fellowship AI007536 and the James W. McLaughlin Fellowship Fund, respectively.

\section{REFERENCES}

1. Britton, P., K. L. Mawditt, and K. W. Page. 1991. The cloning and sequenc ing of the virion protein genes from a British isolate of porcine respiratory coronavirus: comparison with transmissible gastroenteritis virus genes. Virus Res. 21:181-198.

2. Chen, C. M., D. Cavanagh, and P. Britton. 1995. Cloning and sequencing of a 8.4-kb region from the $3^{\prime}$-end of a Taiwanese virulent isolate of the coronavirus transmissible gastroenteritis virus. Virus Res. 38:83-89.

3. de Haan, C. A., P. S. Masters, X. Shen, S. Weiss, and P. J. Rottier. 2002. The group-specific murine coronavirus genes are not essential, but their deletion, by reverse genetics, is attenuating in the natural host. Virology 296:177-189.

4. de Haan, C. A. M., M. Smeets, F. Vernooij, H. Vennema, and P. J. M. Rottier. 1999. Mapping of the coronavirus membrane protein domains involved in interaction with the spike protein. J. Virol. 73:7441-7452.

5. Drosten, C., S. Gunther, W. Preiser, S. van der Werf, H. R. Brodt, S. Becker, H. Rabenau, M. Panning, L. Kolesnikova, R. A. Fouchier, A. Berger, A. M. Burguiere, J. Cinatl, M. Eickmann, N. Escriou, K. Grywna, S. Kramme, J. C. Manuguerra, S. Muller, V. Rickerts, M. Sturmer, S. Vieth, H. D. Klenk, A. D Osterhaus, H. Schmitz, and H. W. Doerr. 2003. Identification of a novel coronavirus in patients with severe acute respiratory syndrome. N. Engl. J. Med. 348:1967-1976.

6. Eleouet, J. F., E. A. Slee, F. Saurini, N. Castagne, D. Poncet, C. Garrido, E. Solary, and S. J. Martin. 2000. The viral nucleocapsid protein of transmissible gastroenteritis coronavirus (TGEV) is cleaved by caspase- 6 and -7 during TGEV-induced apoptosis. J. Virol. 74:3975-3983.

7. Escors, D., C. Capiscol, and L. Enjuanes. 2004. Immunopurification applied to the study of virus protein composition and encapsidation. J. Virol. Methods 119:57-64.

8. Escors, D., J. Ortego, H. Laude, and L. Enjuanes. 2001. The membrane M protein carboxy terminus binds to transmissible gastroenteritis coronavirus core and contributes to core stability. J. Virol. 75:1312-1324.

9. Fischer, F., D. Peng, S. T. Hingley, S. R. Weiss, and P. S. Masters. 1997. The internal open reading frame within the nucleocapsid gene of mouse hepatitis virus encodes a structural protein that is not essential for viral replication. J. Virol. 71:996-1003.

10. Kim, K. H., K. Narayanan, and S. Makino. 1997. Assembled coronavirus from complementation of two defective interfering RNAs. J. Virol. 71:39223931.

11. Ksiazek, T. G., D. Erdman, C. S. Goldsmith, S. R. Zaki, T. Peret, S. Emery, S. Tong, C. Urbani, J. A. Comer, W. Lim, P. E. Rollin, S. F. Dowell, A. E. Ling, C. D. Humphrey, W. J. Shieh, J. Guarner, C. D. Paddock, P. Rota, B Fields, J. DeRisi, J. Y. Yang, N. Cox, J. M. Hughes, J. W. LeDuc, W. J. Bellini, and L. J. Anderson. 2003. A novel coronavirus associated with severe acute respiratory syndrome. N. Engl. J. Med. 348:1953-1966.

12. Lee, N., D. Hui, A. Wu, P. Chan, P. Cameron, G. M. Joynt, A. Ahuja, M. Y. Yung, C. B. Leung, K. F. To, S. F. Lui, C. C. Szeto, S. Chung, and J. J. Sung. 2003. A major outbreak of severe acute respiratory syndrome in Hong Kong. N. Engl. J. Med. 348:1986-1994.

13. Lim, K. P., H. Y. Xu, and D. X. Liu. 2001. Physical interaction between the membrane $(\mathrm{M})$ and envelope $(\mathrm{E})$ proteins of the coronavirus avian infectious bronchitis virus (IBV). Adv. Exp. Med. Biol. 494:595-602.

14. Maeda, J., A. Maeda, and S. Makino. 1999. Release of coronavirus E protein in membrane vesicles from virus-infected cells and E protein-expressing cells. Virology 263:265-272.

15. Makino, S., F. Taguchi, and K. Fujiwara. 1984. Defective interfering particles of mouse hepatitis virus. Virology 133:9-17.
16. Marra, M. A., S. J. Jones, C. R. Astell, R. A. Holt, A. Brooks-Wilson, Y. S. Butterfield, J. Khattra, J. K. Asano, S. A. Barber, S. Y. Chan, A. Cloutier, S. M. Coughlin, D. Freeman, N. Girn, O. L. Griffith, S. R. Leach, M. Mayo, H. McDonald, S. B. Montgomery, P. K. Pandoh, A. S. Petrescu, A. G. Robertson, J. E. Schein, A. Siddiqui, D. E. Smailus, J. M. Stott, G. S. Yang, F. Plummer, A. Andonov, H. Artsob, N. Bastien, K. Bernard, T. F. Booth, D. Bowness, M. Czub, M. Drebot, L. Fernando, R. Flick, M. Garbutt, M. Gray, A. Grolla, S. Jones, H. Feldmann, A. Meyers, A. Kabani, Y. Li, S. Normand, U. Stroher, G. A. Tipples, S. Tyler, R. Vogrig, D. Ward, B. Watson, R. C. Brunham, M. Krajden, M. Petric, D. M. Skowronski, C. Upton, and R. I. Roper. 2003. The genome sequence of the SARS-associated coronavirus. Science 300:1399-1404.

17. Mossel, E. C., C. Huang, K. Narayanan, S. Makino, R. B. Tesh, and C. J. Peters. Exogenous ACE2 expression allows refractory cell lines to support severe acute respiratory syndrome coronavirus replication. J. Virol., in press.

18. Narayanan, K., A. Maeda, J. Maeda, and S. Makino. 2000. Characterization of the coronavirus $\mathrm{M}$ protein and nucleocapsid interaction in infected cells. J. Virol. 74:8127-8134.

19. Narayanan, K., and S. Makino. 2001. Cooperation of an RNA packaging signal and a viral envelope protein in coronavirus RNA packaging. J. Virol. 75:9059-9067.

20. Opstelten, D. J., M. J. Raamsman, K. Wolfs, M. C. Horzinek, and P. J. Rottier. 1995. Envelope glycoprotein interactions in coronavirus assembly. J. Cell Biol. 131:339-349.

21. Ortego, J., I. Sola, F. Almazan, J. E. Ceriani, C. Riquelme, M. Balasch, J. Plana, and L. Enjuanes. 2003. Transmissible gastroenteritis coronavirus gene 7 is not essential but influences in vivo virus replication and virulence. Virology 308:13-22.

22. Paul, P. S., E. M. Vaughn, and P. G. Halbur. 1997. Pathogenicity and sequence analysis studies suggest potential role of gene 3 in virulence of swine enteric and respiratory coronaviruses. Adv. Exp. Med. Biol. 412:317321.

23. Poutanen, S. M., D. E. Low, B. Henry, S. Finkelstein, D. Rose, K. Green, R. Tellier, R. Draker, D. Adachi, M. Ayers, A. K. Chan, D. M. Skowronski, I. Salit, A. E. Simor, A. S. Slutsky, P. W. Doyle, M. Krajden, M. Petric, R. C. Brunham, and A. J. McGeer. 2003. Identification of severe acute respiratory syndrome in Canada. N. Engl. J. Med. 348:1995-2005

24. Prentice, E., J. McAuliffe, X. Lu, K. Subbarao, and M. R. Denison. 2004 Identification and characterization of severe acute respiratory syndrome coronavirus replicase proteins. J. Virol. 78:9977-9986.

25. Rota, P. A., M. S. Oberste, S. S. Monroe, W. A. Nix, R. Campagnoli, J. P. Icenogle, S. Penaranda, B. Bankamp, K. Maher, M. H. Chen, S. Tong, A. Tamin, L. Lowe, M. Frace, J. L. DeRisi, Q. Chen, D. Wang, D. D. Erdman, T. C. Peret, C. Burns, T. G. Ksiazek, P. E. Rollin, A. Sanchez, S. Liffick, B. Holloway, J. Limor, K. McCaustland, M. Olsen-Rasmussen, R. Fouchier, S. Gunther, A. D. Osterhaus, C. Drosten, M. A. Pallansch, L. J. Anderson, and W. J. Bellini. 2003. Characterization of a novel coronavirus associated with severe acute respiratory syndrome. Science 300:1394-1399.

26. Sturman, L. S., K. V. Holmes, and J. Behnke. 1980. Isolation of coronavirus envelope glycoproteins and interaction with the viral nucleocapsid. J. Virol. 33:449-462.

27. Tan, Y. J., E. Teng, S. Shen, T. H. Tan, P. Y. Goh, B. C. Fielding, E. E. Ooi, H. C. Tan, S. G. Lim, and W. Hong. 2004. A novel severe acute respiratory syndrome coronavirus protein, U274, is transported to the cell surface and undergoes endocytosis. J. Virol. 78:6723-6734

28. Thiel, V., K. A. Ivanov, A. Putics, T. Hertzig, B. Schelle, S. Bayer, B. Weissbrich, E. J. Snijder, H. Rabenau, H. W. Doerr, A. E. Gorbalenya, and J. Ziebuhr. 2003. Mechanisms and enzymes involved in SARS coronavirus genome expression. J. Gen. Virol. 84:2305-2315.

29. Tsang, K. W., P. L. Ho, G. C. Ooi, W. K. Yee, T. Wang, M. Chan-Yeung, W. K. Lam, W. H. Seto, L. Y. Yam, T. M. Cheung, P. C. Wong, B. Lam, M. S Ip, J. Chan, K. Y. Yuen, and K. N. Lai. 2003. A cluster of cases of severe acute respiratory syndrome in Hong Kong. N. Engl. J. Med. 348:1977-1985.

30. Vaughn, E. M., P. G. Halbur, and P. S. Paul. 1995. Sequence comparison of porcine respiratory coronavirus isolates reveals heterogeneity in the $\mathrm{S}, 3$, and 3-1 genes. J. Virol. 69:3176-3184.

31. Wesley, R. D., R. D. Woods, and A. K. Cheung. 1991. Genetic analysis of porcine respiratory coronavirus, an attenuated variant of transmissible gastroenteritis virus. J. Virol. 65:3369-3373.

32. Yu, C. J., Y. C. Chen, C. H. Hsiao, T. C. Kuo, S. C. Chang, C. Y. Lu, W. C Wei, C. H. Lee, L. M. Huang, M. F. Chang, H. N. Ho, and F. J. Lee. 2004 Identification of a novel protein $3 \mathrm{a}$ from severe acute respiratory syndrome coronavirus. FEBS Lett. 565:111-116.

33. Zeng, R., R. F. Yang, M. D. Shi, M. R. Jiang, Y. H. Xie, H. Q. Ruan, X. S. Jiang, L. Shi, H. Zhou, L. Zhang, X. D. Wu, Y. Lin, Y. Y. Ji, L. Xiong, Y. Jin, E. H. Dai, X. Y. Wang, B. Y. Si, J. Wang, H. X. Wang, C. E. Wang, Y. H. Gan, Y. C. Li, J. T. Cao, J. P. Zuo, S. F. Shan, E. Xie, S. H. Chen, Z. Q. Jiang, X. Zhang, Y. Wang, G. Pei, B. Sun, and J. R. Wu. 2004. Characterization of the 3a protein of SARS-associated coronavirus in infected Vero E6 cells an SARS patients. J. Mol. Biol. 341:271-279. 